\title{
Defining Properties of Neural Crest-Derived Progenitor Cells from the Apex of Human Developing Tooth
}

\author{
ÖZER DEGISTIRICI, Ph.D., ${ }^{1}$ CLAUDE JAQUIERY, M.D., ${ }^{2}$ BODO SCHÖNEBECK, Ph.D., ${ }^{1}$ \\ JÜRGEN SIEMONSMEIER, M.D., ${ }^{3}$ WERNER GÖTZ, M.D., ${ }^{4}$ IVAN MARTIN, Ph.D., ${ }^{2}$ \\ and MICHAEL THIE, Ph.D. ${ }^{1}$
}

\begin{abstract}
The connective tissue of the human tooth arises from cells that are derived from the cranial neural crest and, thus, are termed as "ectomesenchymal cells." Here, cells being located in a pad-like tissue adjacent to the apex of the developing tooth, which we designated the third molar pad, were separated by the microexplant technique. When outgrowing from the explant, dental neural crest-derived progenitor cells (dNC-PCs) adhered to plastic, proliferated steadily, and displayed a fibroblast-like morphology. At the mRNA level, dNC-PCs expressed neural crest marker genes like Sox9, Snail1, Snail2, Twist1, Msx2, and Dlx6. Cytofluorometric analysis indicated that cells were positive for CD49d ( $\alpha 4$ integrin), CD56 (NCAM), and PDGFR $\alpha$, while negative for CD31, CD34, CD45, and STRO-1. dNC-PCs could be differentiated into neurogenic, chondrogenic, and osteogenic lineages and were shown to produce bone matrix in athymic mice. These results demonstrate that human third molar pad possesses neural crest-derived cells that represent multipotent stem/progenitor cells. As a rather large amount of dNC-PCs could be obtained from each single third molar, cells may be used to regenerate a wide range of tissues within the craniofacial region of humans.
\end{abstract}

\section{INTRODUCTION}

$\mathbf{T}$ THE NEURAL CREST IS AN IMPORTANT transient embryonic tissue that arises along the lateral margins of the neural folds and yields pluripotent cells with migratory properties to generate many different derivatives. In the head, cranial neural crest cells give rise to the ectomesenchyme, from which craniofacial tissues are derived. ${ }^{1-3}$

When the cranial neural crest cells migrate away and travel within the developing head and neck, they are trapped at specific sites of the viscerocranium. These sites include the maxillary and mandibular prominences of the future jaws. ${ }^{4-9}$ While mapping their migration routes, it has been shown that the cranial neural crest cells contribute to the formation of condensed dental mesenchyme, dental papilla, cementum, periodontal ligaments, chondrocytes in Meckel's cartilage, mandible, the articulating disc of the temporomandibular joint, and the branchial arch nerve glia. ${ }^{10,11}$ Therefore, with regard to the development of teeth, all their tissues (except enamel) may, in principle, arise from neural crest-derived ectomesenchymal stem cells.

Several reports have shown that the dental papilla and the dental follicle are developmentally related as they are derived from an early concentration of ectomesenchymal tissue. $^{12,13}$ Not surprisingly, stem cells may contribute to ongoing differentiation and tissue maintenance of the tooth in fetal and postnatal life. For example, stem cells have been described from deciduous and adult dental pulp, ${ }^{14,15}$ from root papilla, ${ }^{16}$ or from periodontal ligament tissue. ${ }^{17}$ Primary cells derived from these tissues are described as

\footnotetext{
${ }^{1}$ Center of Advanced European Studies and Research (CAESAR), Bonn, Germany.

${ }^{2}$ Departments of Surgery and Research, University Hospital, Basel, Switzerland.

${ }^{3}$ Dental Clinic MEDECO, Bonn, Germany.

${ }^{4}$ Oral Biology Laboratory, Department of Orthodontics, Dental Hospital, Bonn, Germany.
} 
STRO-1-positive stem cells. However, details about their properties and functions are still incomplete, and the characterization regarding their relationship is not fully understood.

In line with this, the soft tissue of impacted third molars of young adults was explored as an easily accessible source of high-potent stem cells of ectomesenchymal nature. Here, those cells being located in a pad-like tissue, that is, the apical part of the developing tooth, which we called the third molar pad, were separated by the microexplant technique and culture expanded. We defined the phenotype of a distinct population of progenitor cells, which we termed "dental neural crest-derived progenitor cells" (dNC-PCs), and investigated their in vitro and in vivo growth and their capacity of multilineage differentiation.

As a whole, our data provide evidence that dNC-PCs are novel progenitor cells with a high capacity for diversification when outside their dental signaling network. Thus, the pad-like tissue represents a compartment of the developing tooth where mostly undifferentiated, that is, primitive, cells may be preserved. However, based on expression of specific markers, dNC-PCs are different from adult stem cells that were obtained from dental tissues.

\section{MATERIALS AND METHODS}

\section{Subjects and tissue}

Fully impacted third molars were obtained after being surgically removed from patients of 11-18 years of age due to orthodontics reasons. The average age of patients was 14.3 years $(n=16)$. Written consent was obtained from all parents of the participating patients before extraction. After the surgical procedure, each third molar was immediately transferred into plastic tubes containing transport medium, that is, Dulbecco's modified Eagle's medium-low glucose (DMEM-LG) (Cambrex Bio Science, Verviers, Belgium) supplemented with $1 \%$ penicillin/streptomycin (Cambrex Bio Science).

\section{Cell culture}

Cell preparations were obtained from the apex of the developing tooth, that is, a pad-like tissue that is located under the pulpal tissue as being indicated in Figure $1 \mathrm{~A}-\mathrm{C}$. Under sterile conditions, the pad-like tissue was preprocessed (Supplemental Fig. 1A-G, available online at www .liebertpub.com), cut into small pieces (approximately $1 \mathrm{~mm}^{3}$ ) with a scalpel, and treated with collagenase/dispase solution (Sigma, Munich, Germany) for $1 \mathrm{~h}$ at $37^{\circ} \mathrm{C}$. The resulting preparation was centrifuged at $350 \mathrm{~g}$ for $5 \mathrm{~min}$. The pellet was resuspended in growth medium composed of DMEM-LG supplemented with $2 \mathrm{mM}$ glutamine and $1 \%$ penicillin/ streptomycin (Sigma), and 10\% fetal calf serum (FCS) (Biochrom, Berlin, Germany), and subsequently seeded in T25 tissue culture flasks (BD Falcon, Germany). Microexplants were maintained at $37^{\circ} \mathrm{C}$ in humidified air with $5 \%$ carbon dioxide $\left(\mathrm{CO}_{2}\right)$ for 1-2 weeks; the growth medium was replaced every 3-4 days. Upon reaching 70-80\% confluence, cells were detached using a solution of $0.05 \%$ trypsin/ $0.53 \mathrm{mM}$ ethylenediaminetetraacetic acid (EDTA) (Sigma), washed twice with growth medium, and replated at a density of $5000 \mathrm{cells} / \mathrm{cm}^{2}$. Cell counts were performed using $0.4 \%$ trypan blue solution (Cambrex Bio Science). The population doubling time was calculated according to Bepler et al. ${ }^{18}$ For the described experiments, these cells were used at passages 3 to 4 . Analyses of high passage cultures ( $>$ passage 17) showed spontaneous transformation like chromosomal instability (data not shown) similarly to stem cell systems studied elsewhere. ${ }^{19-21}$

Besides third molar pad-derived cells, also human bone marrow-derived stromal cells (BMSCs) and neonatal dermal fibroblasts (NDFBs) (Cambrex Bio Science) were used in some experiments as terms of comparison.

\section{In vitro differentiation}

For neurogenic differentiation, high-density cultures $\left(2 \times 10^{4}\right.$ cells $\left./ \mathrm{cm}^{2}\right)$ were maintained in neurobasal medium (Invitrogen, Carlsbad, CA) supplemented with $1 \times$ B27 (Invitrogen), $20 \mathrm{ng} / \mathrm{mL}$ epidermal growth factor (Sigma), and $40 \mathrm{ng} / \mathrm{mL}$ basic fibroblast growth factor (bFGF) (Sigma). After 4-7 days, free-floating spheres were collected, trypsinized, and replated at a density of 5000 cells $/ \mathrm{cm}^{2}$ on glass cover slips coated with poly-D-lysine/laminin (BD Biosciences, San Jose, CA). Cells were further incubated in differentiation medium, that is, DMEM supplemented with $15 \%$ FCS (Biochrom), $50 \mathrm{ng} / \mathrm{mL} \beta$-nerve growth factor, $20 \mathrm{ng} / \mathrm{mL}$ bFGF, $1 \mathrm{mM}$ dibutyryl cAMP, $0.5 \mathrm{mM} 3$-isobutyl1-methylxanthine, and $10 \mu \mathrm{M}$ all trans-retinoic acid (all from Sigma). Differentiation medium was changed every second day. $^{22}$

For chondrogenic induction, the three-dimensional micromass cultures (pellet cultures) were performed. ${ }^{23}$ About $2 \times 10^{5}$ cells were placed in a $15-\mathrm{mL}$ polypropylene tube (BD Falcon) and pelleted at $400 \mathrm{~g}$ for $5 \mathrm{~min}$ at $4{ }^{\circ} \mathrm{C}$. Then, the medium was changed and samples were grown in chondrogenic medium consisting of DMEM-high glucose (Cambrex Bio Science) supplemented with L-glutamine, $100 \mu \mathrm{g} / \mathrm{mL}$ sodium pyruvate, $50 \mu \mathrm{g} / \mathrm{mL}$ L-ascorbic acid-2phosphate, $10^{-7} \mathrm{M}$ dexamethasone, $1 \%$ ITS +1 (insulin, transferrin, and selenium), and $10 \mathrm{ng} / \mathrm{mL}$ recombinant human transforming growth factor- $\beta 1$ (all from Sigma). Pellets were cultured at $37^{\circ} \mathrm{C}$ in humidified air with $5 \% \mathrm{CO}_{2}$. After 2 weeks, $500 \mathrm{ng} / \mathrm{mL}$ recombinant human bone morphogenetic protein-6 (Sigma) was added. The differentiation medium was changed every second day. Cultures were analyzed after 21 and 28 days.

For osteogenic induction, cells were initially seeded at a density of $8 \times 10^{3}$ cells $/ \mathrm{cm}^{2}$ in 24 -well plates (BD Falcon) and cultured in growth medium containing DMEM-LG, $10 \%$ FCS, and $1 \%$ penicillin/streptomycin. When reaching subconfluency, cultures were further grown in differentia- 

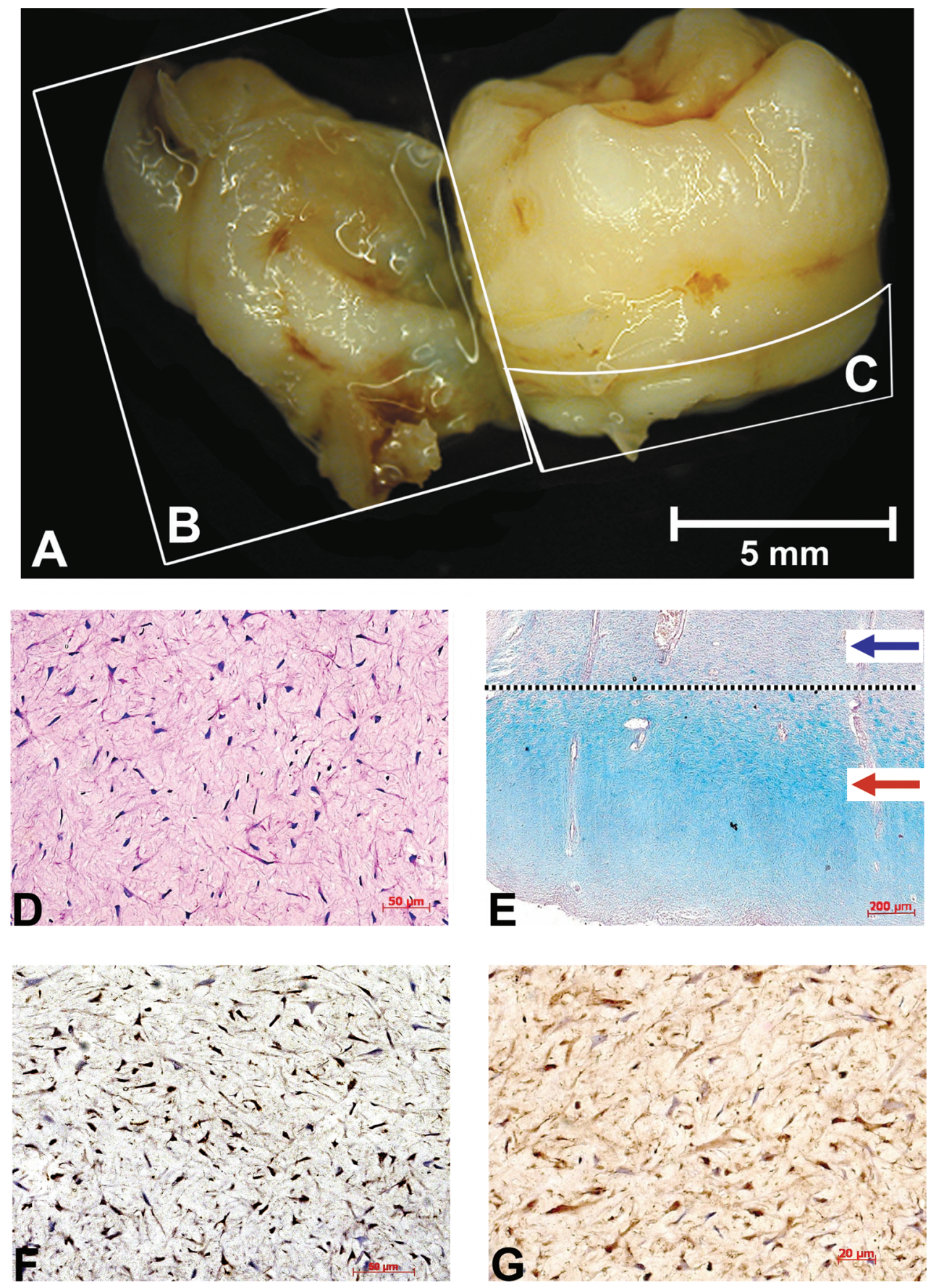

FIG. 1. Maxillary third molar. Lateral view of the impacted molar that has been surgically removed and partially dissected (A). Under these conditions the connective tissues enveloping the immature tooth appear detached (B), while the pad-like tissue remains correctly beneath the papilla $(\mathbf{C})$. Sections of the pad-like tissue (D-G): histologic appearance by hematoxylin and eosin-periodic acid Schiff (D) and Alcian blue (E; dotted line indicates transition between pulpal tissue [blue arrow] and pad-like tissue [red arrow]); immunolocalization of single cells positive for antibodies to SOX9 (F) and MSX2 (G), respectively. Color images available online at www.liebertpub.com/ten.

tion medium, that is, growth medium supplemented with $10^{-7} \mathrm{M}$ dexamethasone, $50 \mu \mathrm{M}$ ascorbic acid-2 phosphate, and $10 \mathrm{mM} \beta$-glycerol phosphate (all from Sigma). ${ }^{24}$ The medium was changed twice a week, and cultures were analyzed after 14, 21, and 28 days.

\section{In vivo osteogenesis}

Monolayer cultured cells (see "cell culture," above) were trypsinized and resuspended in fibrin gel (Baxter, Wien, Austria), and statically loaded into bovine bone-derived 
granulates $(250-500 \mu \mathrm{m}$ particles; Bio-Oss, Geistlich, Switzerland). ${ }^{25}$ Briefly, $1 \times 10^{6}$ cells were resuspended in $30 \mu \mathrm{L}$ of the fibrinogen component (diluted to $20 \mathrm{mg} / \mathrm{mL}$ ), quickly mixed with $30 \mu \mathrm{L}$ of the thrombin component (diluted to $6 \mathrm{IU} / \mathrm{mL}$ ), and immediately loaded into and around the scaffolds, where fibrin polymerized during incubation for $15 \mathrm{~min}$ in a humidified $5 \% \mathrm{CO}_{2}$ incubator at $37^{\circ} \mathrm{C}$. The cell-fibrin-scaffold constructs were harvested and implanted subcutaneously in nude mice (CD-1 nude/nude, Charles River, Wilmington, MA). As a negative control, fibrinscaffolds without cells were implanted. Care of animals was in accordance with institutional guidelines. After 5 and 10 weeks, respectively, mice were killed and explants were fixed in $4 \%$ formaldehyde, and embedded in paraffin. Sections were stained with hematoxylin and eosin and Masson's trichrome, and assessed by computerized histomorphometry. ${ }^{26}$

\section{RT-PCR analysis}

Total RNA was isolated from tissues or cells by adding Qiazol lysis reagent ${ }^{\circledR}$ (Qiagen, Hilden, Germany) to samples. Samples were homogenized in a TissueLyser ${ }^{\circledR}$ (Qiagen). After precipitation, RNA was purified by using Qiagen Miniprep ${ }^{\circledR}$ protocol, including on column DNAse A digestion according to the manufacturer's recommendations (Qiagen). cDNA was synthesized according to instructions of RevertAid H Minus First Strand cDNA Synthesis Kit ${ }^{\circledR}$ (Fermentas, Burlington, Canada). PCR was performed by using cDNA as template and Taq PCR Master Mix $\mathrm{Kit}^{\circledR}$ (Qiagen) with a final concentration of forward and reverse primers of $0.4 \mu \mathrm{M}$. All genes were amplified in an Eppendorf PCR master cycler (Eppendorf, Hamburg, Germany) with an annealing temperature of $55^{\circ} \mathrm{C}$ for a total of 36 cycles excluding aggrecan which was carried out with Phusion polymerase, GC buffer, and a final concentration of $4 \%$ dimethyl sulfoxide (Finnzymes Oy, Espoo, Finland) at an annealing temperature of $58^{\circ} \mathrm{C}$. After gel electrophoresis, PCR products were visualized with Gel Doc 2000 system (BioRad, Munich, Germany). Glyceraldehyde-3-phosphatase dehydrogenase (GAPDH) and $\beta$-2-microglobulin served as housekeeping genes. Primers used are listed in Supplemental Table 1 (available online at www.liebertpub.com).

\section{Real-time PCR}

Quantitative PCR was performed by using cDNA as a template and QuantiTect Primer Assays (Qiagen) in a DNA Engine Opticon real-time cycler with fluorescent SYBR Green detection. The PCR was performed by using the $2 \times$ QuantiTect SYBR Green PCR Master Mix starting with an initial incubation step of $15 \mathrm{~min}$ at $95^{\circ} \mathrm{C}$ to activate HotStarTaq DNA Polymerase (Qiagen). A total of 40 cycles were executed with $15 \mathrm{~s}$ for denaturation at $94^{\circ} \mathrm{C}$ and an annealing temperature of $55^{\circ} \mathrm{C}$ for $30 \mathrm{~s}$ followed by an extension period of $30 \mathrm{~s}$ at $72^{\circ} \mathrm{C}$. After the last cycle was finished, all products were denaturated for melting curve analysis. Each PCR reaction contains $5 \mu \mathrm{L}$ of prediluted QuantiTect Primer Assays (neurofilament 3 [NEF3]: Hs_NEF3_1_SG, NM_005382; NEFH: Hs_NEFH_1_SG, NM_021076; myelin basic protein [MBP]: Hs_MBP_1_SG, NM_002385) per the manufacturer's (Qiagen) recommendations in a total volume of $40 \mu \mathrm{L}$. A QuantiTect Primer Assay for GAPDH was used as an internal housekeeping control. A threshold line was adjusted to a value above the baseline in the starting phase of the loglinear range of the PCR resulting in corresponding threshold cycles (CT) of the samples. The relative differences in gene expression were calculated by taking corresponding expression values of the GAPDH housekeeper into account and are analyzed via the $\Delta \Delta \mathrm{CT}$ method.

\section{Flow cytometric analysis}

Flow cytometry was performed on monolayer cultured cells (see "cell culture," above). Cells were harvested by treatment with trypsin-EDTA (Sigma), washed twice with phosphate-buffered saline (PBS) containing $0.1 \%$ bovine serum albumin (BSA) and $0.01 \%$ sodium azide, and resuspended in buffer. For staining, aliquots of $1 \times 10^{5}$ cells/ $100 \mu \mathrm{L}$ PBS-BSA were incubated with monoclonal antibodies tagged with fluorescent label for $45 \mathrm{~min}$ on ice. Thereafter, samples were washed twice with PBS-BSA and analyzed on a fluorescence-activated cell sorter system FACSAria $^{\mathrm{TM}}$ (BD Biosciences) by collecting 10,000 events. Flow cytometry data were analyzed using the FlowJo software (version 7; Tree Star, Ashland, OR). The antibodies used are listed in Supplemental Table 2 (available online at www.liebertpub.com). In controls, isotypic antibodies (fluorescein isothiocyanate [FITC], PE, and allophycocyanin [APC]) were used (BD Biosciences). Antibody against STRO-1 was obtained from R\&D Systems (Minneapolis, $\mathrm{MN}$ ), and secondary anti-mouse immunoglobulin M antibody conjugated with FITC was obtained from Biosciences.

\section{Assay of alkaline phosphatase activity}

Alkaline phosphatase activity was determined in cell lysates using $p$-nitrophenyl phosphate as a substrate (Sigma). The procedure was carried out as recommended by the manufacturer. Briefly, cells growing on 24-well plates (BD Falcon) were washed with PBS and incubated with $1 \%$ Triton X-100 (Sigma). The resulting lysate was then incubated with substrate, and the released $p$-nitrophenol was measured at $405 \mathrm{~nm}$ (PerkinElmer, Waltham, MA). The alkaline phosphatase activity values were normalized to the total protein (NANOdrop; Agilent, Santa Clara, CA). Alkaline phosphatase activity was expressed as $\mu \mathrm{M} p$ nitrophenol/L/min/sample.

\section{Quantification of sulfated glycosaminoglycans}

The totality of sulfated glycosaminoglycans (S-GAGs) was quantified after cultivating cells under chondrogenic 
conditions as described above. Pellet cultures were washed with PBS and then solubilized by digestion for $4 \mathrm{~h}$ at $65^{\circ} \mathrm{C}$ with $25 \mu \mathrm{g} / \mathrm{mL}$ papain in $2 \mathrm{mM}$ EDTA, $50 \mathrm{mM}$ sodium sulfate, and $2 \mathrm{mM} \mathrm{N}$-acetyl cysteine (all from Sigma). For the calculation of S-GAGs, the digest was stained with dimethylmethylene blue (Serva, Amstetten, Germany). ${ }^{27}$ The samples were measured at $595 \mathrm{~nm}$ (PerkinElmer) in triplicate, and content of S-GAGs was expressed as ng/pellet.

\section{Quantification of calcium}

The total calcium of the samples was measured by the $o$ cresolphthalein complexone method using the commercial Calcium Assay-CA590 kit (Randox Laboratories, Co Antrim, United Kingdom). The procedure was carried out according to the manufacturer's protocol. Briefly, cells growing on 24-well plates (Falcon) were washed with PBS and extracted in $200 \mu \mathrm{L}$ of $0.5 \mathrm{~N}$ hydrochloric acid for $5 \mathrm{~min}$. Then samples were vigorously shaken for $4-16 \mathrm{~h}$ at $4^{\circ} \mathrm{C}$. Calcium determination was done in 96-well plates with $10 \mu \mathrm{L}$ of test solution and $90 \mu \mathrm{L}$ of substrate solution mixed up with $100 \mu \mathrm{L}$ of distilled water. The amount of deposited calcium was determined at $570 \mathrm{~nm}$ using a spectrofluorometer (PerkinElmer) and was expressed as $\mu \mathrm{g} / \mathrm{cm}^{2}$.

\section{Immunohistochemistry}

Immunohistochemical analyses of the pad-like tissue were performed with monoclonal antibodies to SOX9 and MSX2 (both from Abcam, Cambridge, United Kingdom). The pad-like tissue was fixed in $4 \%$ formaldehyde, dehydrated, and embedded in paraffin. Ten-micron sections were rinsed in PBS at room temperature and incubated with primary antibodies in 1:200 dilutions overnight. Thereafter, samples were washed twice for $10 \mathrm{~min}$ in Tris-buffered saline (TBS) and incubated with peroxidase-conjugated goat anti-mouse immunoglobulin G (diluted 1:100 in TBSBSA) (Biozol, Eching, Germany) at room temperature for $1 \mathrm{~h}$. After a rinse, peroxidase activity was visualized with diaminobenzidine. Slides were counterstained with Mayer's hematoxylin.

Cells cultured for neurogenic differentiation were fixed for 15 min with $4 \%$ formaldehyde in PBS, washed in PBS, and preincubated in $10 \%$ normal goat serum with $0.03 \%$ Triton X-100 at room temperature for $30 \mathrm{~min}$ to block nonspecific binding. Then, incubation with the primary antibody at $4^{\circ} \mathrm{C}$ followed overnight. Subsequently, the samples were rinsed in PBS for $15 \mathrm{~min}$ and incubated with the corresponding fluorescence-conjugated secondary antibody for $60 \mathrm{~min}$ at room temperature. The primary antibodies used were mouse monoclonal antibody to pan-neurofilament (neurofilament $\mathrm{M}-\mathrm{H}$; diluted 1:1000; Invitrogen), rabbit polyclonal antibodies to glial fibrillary acidic protein (GFAP; diluted 1:300; Chemicon, Temecula, CA), and MBP (diluted 1:200; Chemicon). Secondary antibodies (labeled with Alexa green and Alexa red) were obtained from Mo- lecular Probes (Carlsbad, CA) and used in 1:1000 dilutions in PBS. 4',6-Diamino-2-phenylindole (DAPI) was used to counterstain the nuclei. Fluorescence microscopy was performed using a Zeiss microscope.

\section{Histology}

Surgically removed complete, immature wisdom teeth including follicular and apical tissue were fixed in $4 \%$ formaldehyde in PBS for at least $24 \mathrm{~h}$ and decalcified in $10 \%$ EDTA. After dehydration in an ascending ethanol series and paraffin embedding, 5- $\mu \mathrm{m}$ serial sections were cut in an occlusal-apical direction and mounted on glass slides. In the same manner, the pellets from chondrogenic differentiation were processed, however, without decalcification. Simply, monolayer cultured cells were rinsed twice in PBS, fixed in $4 \%$ formaldehyde in PBS for $20 \mathrm{~min}$, and subsequently washed in PBS. Selected sections were stained routinely with hematoxylin and eosin, and periodic acid Schiff (PAS) or Alcian blue or toluidine blue staining for detection of glycoproteins and proteoglycans. To identify the formation of mineralization, monolayers were stained with von Kossa at room temperature. ${ }^{24}$

\section{Data analysis}

Each assessment was performed on two or more independent cultures or constructs for each donor, cell source, and experimental group. All values are expressed as mean \pm standard error of the mean. Gene expression data were analyzed with the software WinStat (version 2005.1) for Microsoft Excel. Data were checked according to normal distribution following analysis of variance (ANOVA) at $p$-values of $0.05,0.01$, and 0.001 .

\section{RESULTS}

\section{The third molar pad (pad-like tissue)}

Proper dissection of the tooth was a prerequisite to obtain suitable tissue for subsequent isolation of cells. Thus, the method of gross sectioning was standardized (Fig. 1A-C; Supplemental Fig. 1A-G). Each extracted molar was cleaned of surrounding tissue (operculum, periodontal ligament, and follicle, respectively) (Fig. 1B) and subsequently cut with a scalpel at the root diaphragm, which is now easily discernible. Thereby, it was possible to dissect it from the hard and pulpal tissue while obtaining the pad-like tissue (Fig. 1C).

Histological sections of the immature third molars revealed the typical hard and soft tissue components: dentin crown with beginning root formation and cementogenesis, occlusal connective tissues, and reduced enamel epithelia, differentiating periodontal ligament with alveolar bone fragments (data not shown). Apically of the pulpal tissue and demarcated by the root diaphragm, a loose connective mesenchymal tissue containing undifferentiated fibroblastic 
cells with sparse vascularization was found (Fig. 1D) and designated as pad-like tissue. In contrast, the pulpal tissue consisted of a more dense cellular and fibrous tissue containing more vessels and nerves. The pad-like tissue was also clearly demarcated from the papilla by intensive alcianophilia indicating richness in proteoglycans (Fig. 1E: red arrow shows pad-like tissue; blue arrow shows pulpal/ papilla tissue). Due to their affinities for various antibodies, connective tissue cells of the pad may be functionally different; that is, subpopulations of cells reactive for the neural crest lineage marker SOX9 (Fig. 1F), and the ectomesenchymal lineage marker MSX2 (Fig. 1G) were observed.

\section{Isolation of dental dNC-PCs}

Cultures were prepared from pad-like tissue-derived microexplants that adhered to the plastic surface. Within 2-3 days, explants started to release migratory cells (Fig. $2 \mathrm{~A}$ and inset $\mathrm{A}^{\prime}$ ). After the onset of cell motility, cells were
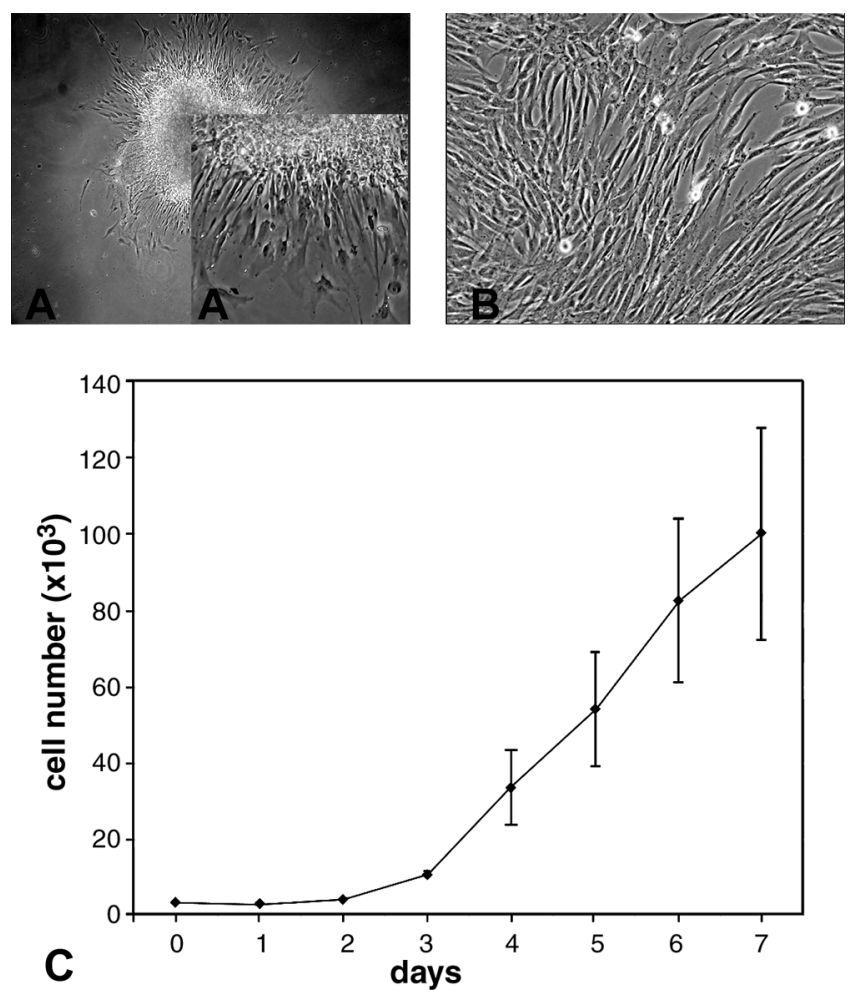

FIG. 2. The appearance of dNC-PCs cultured on plastic. Note the migratory behavior of cells when microexplants start to release cells $\left(\mathbf{A}, \times 50\right.$; inset $\left.A^{\prime}, \times 630\right)$. The cells are characterized by a fibroblastoid phenotype when cultured in passage $2(\mathbf{B}, \times 100)$. Growth curve of dNC-PCs cultured on plastic $(\mathbf{C})$. Cells were plated at a density of 5000 cells $/ \mathrm{cm}^{2}$ and cultured in growth medium supplemented with $10 \%$ FCS for 7 days. Cells were harvested each day and counted with a hemocytometer. Values expressed are the mean \pm SEM of triplicate determinations from three third molars. The mean cumulative time of population doublings of cultured cells (passage 3 ) is $35 \pm 7 \mathrm{~h}$. seen initially to migrate away in a radial manner. Upon reaching subconfluence, growing cells were detached and replated. They then spread and crawled out over the plastic surface of the culture dish. Typically, single cells were fibroblastoid in shape. During the expansion phase, cells divided rapidly forming a monolayer (Fig. 2B). After a total period of 15 days, it was possible to obtain around $0.5-1 \times 10^{6}$ cells from a single pad-like tissue. A diagram typical for the growth kinetics of adherent cells from passage 3 is shown in Figure 2C. Growth curves depicted an initial lag phase of 2 days, followed by an exponential log phase for 3-5 days. The mean cumulative time of population doublings was about $35 \pm 7 \mathrm{~h}$. Pad-like tissue-derived cells, which had been grown over a longer period, up to passage 20 , did not lose their capacity to proliferate, although their proliferation rate strongly decreased and the size of cells slightly increased.

\section{Characterization of $d N C$-PCs}

The population of adherent cells, which was obtained from the pad-like tissue by the technique described above, was analyzed by flow cytometry (Table 1 and Fig. 3A). Human bone marrow stromal cells served as comparison. A characteristic pattern of markers was observed for both cell populations that allowed to discern and to define pad-like tissue-derived and bone marrow-derived cells (Table 1). Typically, pad-like tissue-derived cells showed high values of expression for CD10, CD49b, CD49d, CD54, CD56, and PDGFR $\alpha$, while bone marrow-derived cells showed low values for these markers. In contrast, pad-like tissuederived cells showed a low value of expression for CD105 and CD106 and no expression for STRO-1, while bone marrow cells showed high levels. Markers that were also found in both cell types but did not differ with respect to their value of expression are CD9, CD13, CD29, CD44, CD49e, CD73, CD90, CD117, CD140b, CD147, CD166, and class I HLA. Pad-like tissue-derived cells displayed no expression of hematopoietic markers (CD14, CD34, and CD45), markers known for endothelial cells (CD31 and CD51/61), pan-cytokeratin, and class II HLA. Since antibodies cross-reacting against $\mathrm{CD}$ are not available for all proteins, mRNA expression of six genes related to identification of the neural crest and ectomesenchymal lineage was examined (Fig. 3B). dNC-PCs displayed expression of early neural crest markers Snail1, Snail2, Sox9, Twist1, and ectomesenchymal markers Msx2 and Dlx6. In accordance, these markers were also detected in the pad-like tissue itself from which dNC-PCs were isolated.

\section{Neurogenic differentiation}

To show neurogenic capacity of dNC-PCs in vitro, cells (six individuals; patient numbers $1,2,4,8,15$, and 16) were cultivated in neurogenic medium. While cells cultured in standard medium proliferated and maintained their fibroblastic morphology still after 14 days (Fig. 4A), neurogenic- 
Table 1. Flow Cytometric Analysis of dNC-PCs Using the BD FACSAria Flow Cytometer

\begin{tabular}{|c|c|c|}
\hline Antibodies & $d N C$-PCs $(\%$ mean $\pm S D, \mathrm{n}=6)$ & $h B M S C s(\%$ mean $\pm S D, \mathrm{n}=3)$ \\
\hline \multicolumn{3}{|l|}{ Adhesion molecules } \\
\hline CD147 (neurothelin) & $98.3 \pm 0.8$ & $87 \pm 15.1$ \\
\hline CD166 (alcam) & $95.3 \pm 5.1$ & $78.3 \pm 19.1$ \\
\hline CD44 (hyaluronate receptor) & $84.2 \pm 13.8$ & $75.7 \pm 7.5$ \\
\hline CD56 (NCAM) & $53.1 \pm 17.3$ & $5.8 \pm 4.7$ \\
\hline CD54 (ICAM-1) & $28.5 \pm 13$ & $7.4 \pm 4.6$ \\
\hline CD106 (VCAM) & $4.2 \pm 3.4$ & $13.7 \pm 8$ \\
\hline CD45 (leukocyte antigen) & 0 & $3 \pm 3.4$ \\
\hline CD31 (PECAM) & 0 & 0 \\
\hline CD51/61 (vitronectin R) & 0 & 0 \\
\hline \multicolumn{3}{|c|}{ Growth factors and cytokine receptors } \\
\hline CD140b (PDGFBB) & $98.3 \pm 1.7$ & $96.7 \pm 2.1$ \\
\hline $\operatorname{PDGFR} \alpha$ & $84.3 \pm 11.2$ & $28.3 \pm 15.2$ \\
\hline CD117 (c-kit) & $73.3 \pm 13.4$ & $51.3 \pm 29.5$ \\
\hline CD105 (endoglin) & $43.8 \pm 28.2$ & $86.3 \pm 13.6$ \\
\hline \multicolumn{3}{|l|}{ Integrins } \\
\hline CD29 (VLA- $\beta$ chain) & $98.7 \pm 0.8$ & $86 \pm 15.1$ \\
\hline CD49e (VLA- $\alpha 5)$ & $95 \pm 9.3$ & $88.3 \pm 11.6$ \\
\hline CD49d (VLA- $\alpha 4)$ & $76.8 \pm 7$ & $17.3 \pm 14.3$ \\
\hline CD49b (VLA- $\alpha 2)$ & $57.7 \pm 22.9$ & $13 \pm 4.4$ \\
\hline \multicolumn{3}{|l|}{ Others } \\
\hline CD90 (Thy-1) & $97.7 \pm 2$ & $95 \pm 4$ \\
\hline CD10 (neprilysin, ecto-enzyme) & $\mathbf{9 7} \pm \mathbf{2}$ & $18.2 \pm 15.3$ \\
\hline CD73 (5'-terminal nucleotidase) & $93 \pm 4.1$ & $81.3 \pm 14.6$ \\
\hline CD13 (aminopeptidase) & $76 \pm 24.7$ & $64.8 \pm 55.8$ \\
\hline CD9 (tetraspan) & $75.5 \pm 14.8$ & $56 \pm 24.3$ \\
\hline Class I HLA (ABC) & $64.3 \pm 25.3$ & $31.6 \pm 22.4$ \\
\hline Pan-cytokeratin & 0 & 0 \\
\hline STRO-1 & $\mathbf{0}$ & $4 \pm 2.2$ \\
\hline CD14 (LPS receptor) & 0 & 0 \\
\hline Class II HLA (DR) & 0 & 0 \\
\hline CD34 & 0 & 0 \\
\hline
\end{tabular}

The analysis features in FlowJo software (Tree Star) were used to create the accurate percentages of antibody staining. For comparison, human BMSCs were used. For clarity, individual antibodies are clustered in functional groups. In addition, markers differentially expressed in dNC-PCs and BMSCs are set in boldface.

stimulated cell cultures exhibited changes. The formation of diverse cell types of nervous tissue was observed 7 days (Fig. 4B) and 14 days (Fig. 4C) after the neurogenic stimulation. Some cells showed a neuronal morphology, that is, a large cell body with a number of long, thin processes radiating out of it. With prolonged culture time, the number of these elongated cells increased continuously. Many cells with a nervous tissue-like morphology showed positive staining against neuronal marker pan-neurofilament (stained neurofilament chain $\mathrm{M}$ and $\mathrm{H}$ ) (Fig. 4D-F), Schwann cell marker MBP (Fig. 4G-I), and astrocyte marker GFAP (Fig. 4J-L) after 14 days. Further indications for neurogenic differentiation were obtained by semiquantitative RT-PCR analysis of stimulated cultures. Under prolonged culture conditions, cells showed an upregulation of MBP, NEF3, and neurofilament H (Fig. 4M).

\section{Chondrogenic differentiation}

Pellet cultures of dNC-PCs (four individuals; patient numbers $1,2,7$, and 8) exhibited an increase in size after chondrogenic stimulation. The morphology of pellets showed rounded cells, which were isolated from one another throughout the pellet. These cells (except for patient 7) secreted large quantities of collagenous extracellular matrix so that cells were embedded in their own matrix. A relatively strong toluidine blue staining was observed around the cells indicating the presence of highly sulfated proteoglycans (Fig. 5A). Indeed, the content of S-GAGs showed a 10-fold increase after 21 days of cultures (Fig. 5B). The RT-PCR analysis of pellets revealed upregulation of cartilage oligomatrix protein, type II collagen, and aggrecan, again indicating chondrogenic differentiation (Fig. 5C). 

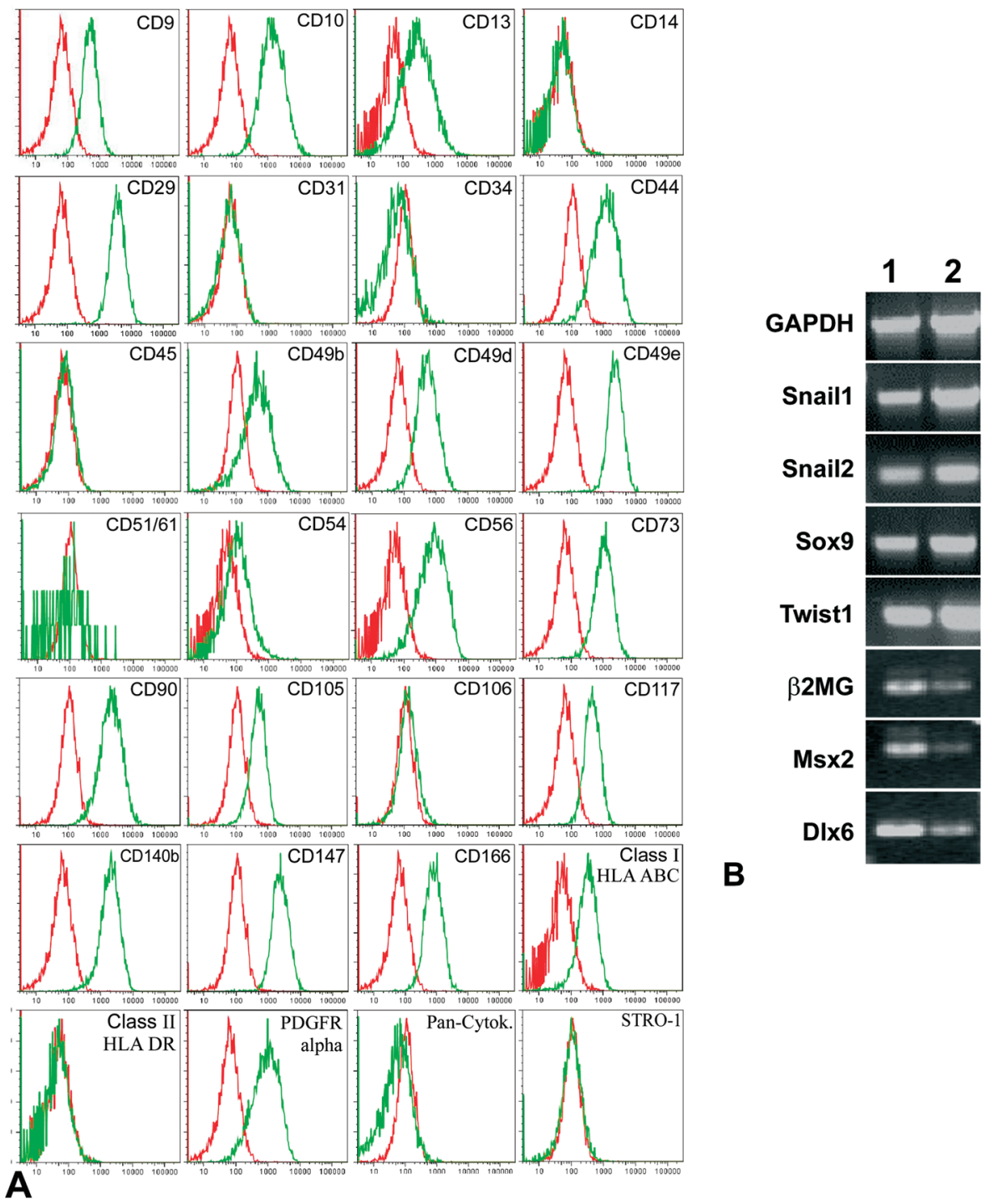

B

FIG. 3. Characteristics of cultured dNC-PCs. Typical flow cytometric analysis diagrams (A) on the expression of antigens listed in Supplemental Table 1. Red histogram: peak of isotype control; green histogram: peak of each marker expression. See also Table 1. RTPCR of pad-like tissue and dNC-PCs isolated thereof (B). Note positive expression of Snail1, Snail2, Sox9, and Twist1 (neural crest markers) and of Msx2 and Dlx6 (dental ectomesenchyme markers), respectively. GAPDH and $\beta$-2-microglobulin ( $\beta 2 \mathrm{MG})$ served as housekeeping genes. Pad-like tissue (1); dNCPCs (2). Color images available online at www.liebertpub.com/ten.

\section{Osteogenic differentiation}

After 21 days of osteogenic stimulation (14 individuals; patient numbers $1,2,3,4,5,6,7,8,9,10,13,14,15$, and 16), cultures of dNC-PCs exhibited substantial deposits of calcium salts in the extracellular matrix (Fig. 6A and inset $\mathrm{A}^{\prime}$ ), while the control cultures were negative (Fig. 6B). As shown by RT-PCR, osteocalcin expression increased after osteogenic stimulation, while alkaline phosphatase expression was detected in osteogenic-stimulated cultures as well as in control cultures (Fig. 6C). A quantitative analysis of total calcium showed that stimulated cultures exhibited higher values than controls at day 21 (Fig. 6D). Alkaline phosphates activity increased continuously in osteogenicstimulated cultures and in control cultures (Fig. 6E).

\section{In vivo osteogenesis}

The bone formation capacity of dNC-PCs (three individuals; patient numbers 1,2 , and 8 ) was assayed by ectopic implantation of cell-fibrin-scaffold constructs in nude mice. Bone matrix could be observed in 12 out of $24(50 \%)$ constructs loaded with dNC-PCs (Fig. 6F). Samples from all three tested donors (male, 16 years; male, 15 years; female, 15 years) could generate bone tissue. Compared to 

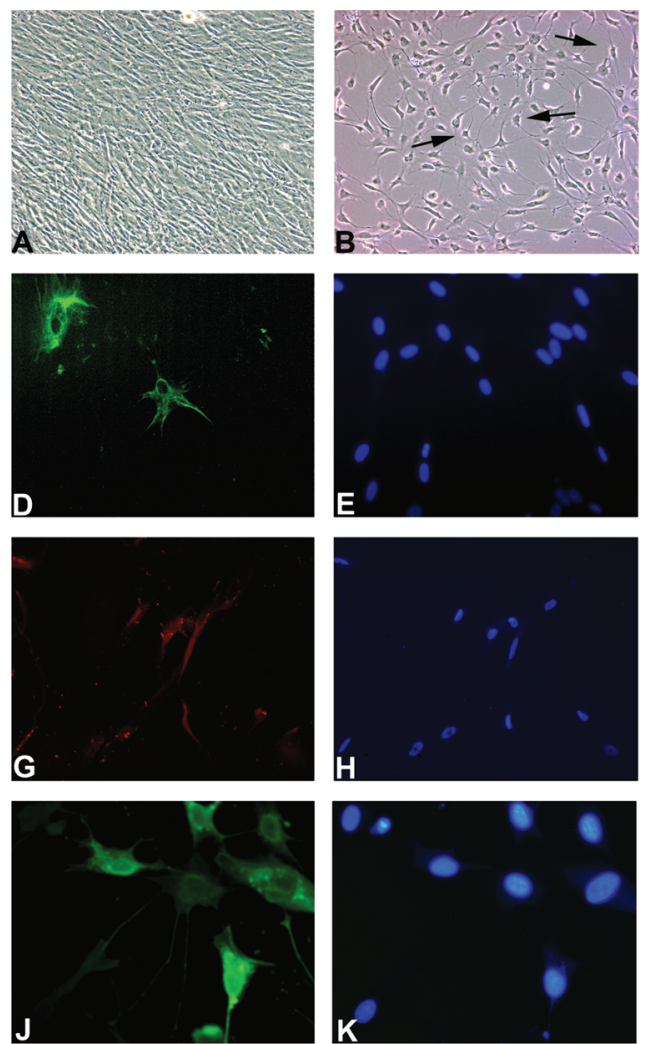
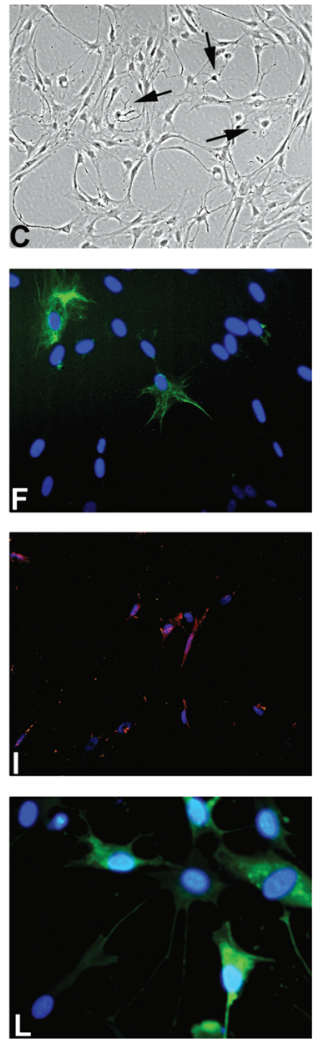
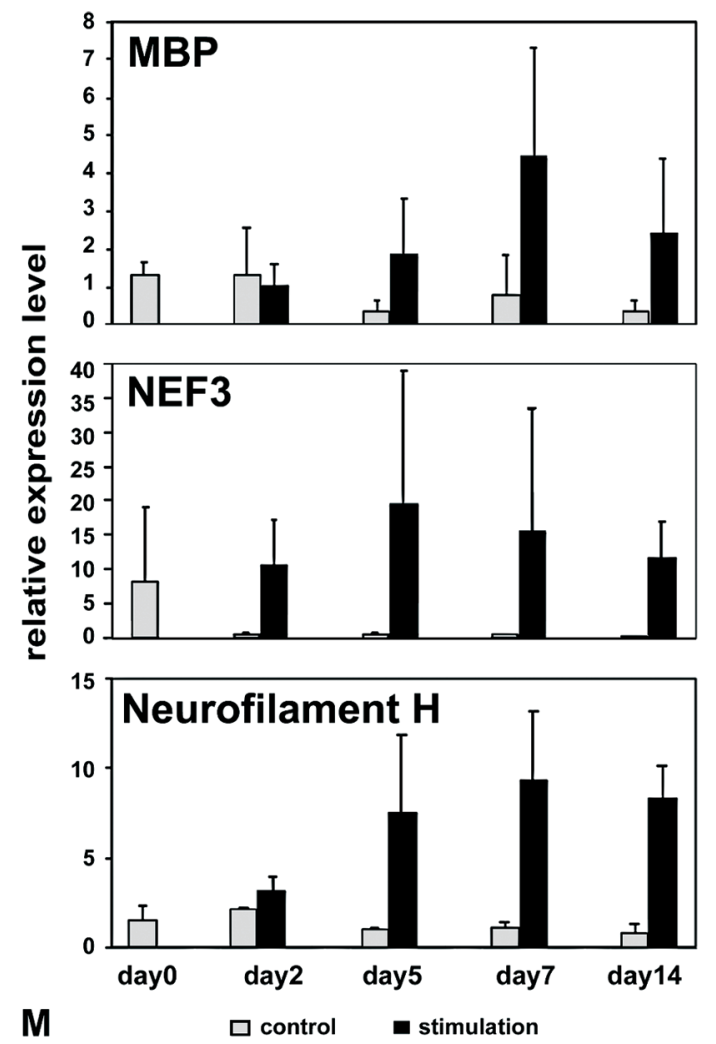

FIG. 4. Characterization of dNC-PCs after neurogenic stimulation. Cells exhibit fibroblastoid morphology after 14 days in standard growth medium $(\mathbf{A}, \times 100)$. Single cells (arrows) showed neurogenic morphology 7 days $(\mathbf{B}, \times 100)$ and 14 days $(\mathbf{C}, \times 100)$ after stimulation. Immunolocalization of cells positive for antibodies to pan-neurofilament (D-F, $\times 200$; green), MBP $(\mathbf{G}-\mathbf{I}, \times 100$; red), and GFAP (J-L, ×400; green). Nuclei are stained with DAPI (E, H, K; blue). Merger of staining with antibodies and DAPI (F, I, L). Semiquantitative RT-PCR analysis of dNC-PCs after neurogenic stimulation (M). Expression levels of MBP, NEF3, and neurofilament H increased during the course of neurogenic differentiation. The expression of genes was evaluated using GAPDH as housekeeper. Day 0 referred to basic expression values followed by days 2, 5, 7, and 14 after onset of stimulation. Color images available online at www.liebertpub.com/ten.

constructs loaded with bone marrow stromal cells (used as a positive control for in vivo osteogenic differentiation), the frequency of bone formation was almost identical; that is, 7 out of 16 constructs $(43.5 \%)$ showed bone formation (Fig. 6G). Scaffolds not loaded with cells did not show any bone formation (Fig. $6 \mathrm{H}$ ). Due to undegraded scaffolds, the percentage of bone per total implant area (Fig. 6I) and of bone per total space available for tissue ingrowth was distinct (Fig. 6J). For constructs that were harvested after 10 weeks, the average percentage of bone tissue reached $8.4 \%$ of the total tissue formed for pad-like tissue-derived cells as well as in constructs loaded with bone marrow stromal cells (Fig. 6J). Constructs harvested after 5 weeks showed general low amounts of bone formation and reached an average $1.5 \%$ bone of total tissue formed for both cell types (Fig. 6J). Morphological analysis showed that the newly formed bone matrix was deposited starting from the surface of the ceramic. This freshly formed material was secreted by cells that lie at the surface of the matrix. The bone tissue generated appeared already remodeled and lamellar. With regard to morphology, tubular dentin forma- tion could not be observed. Moreover, no tumor formation was observed in any animal.

\section{DISCUSSION}

We have evaluated the properties of progenitor cells isolated from a pad-like tissue of human impacted third molars by in vitro and in vivo analysis. We have found that the pad-like tissue-derived cells, which we termed dental dNC-PCs, represent a population of migratory progenitor cells, which formed diverse cell types outside their environment. For example, cells developed into neurogenic, chondrogenic, and osteogenic lineages. Pad-like tissuederived cells expressed a distinct set of markers, including those for neural crest and ectomesenchyme. Further studies showed that the pad-like tissue-derived cells differ from mesenchymal progenitor cells derived from the bone marrow. In general, our data indicate that the pad-like tissue may be a useful source for novel neural crest-derived ectomesenchymal progenitor cells, that is, dNC-PCs. 


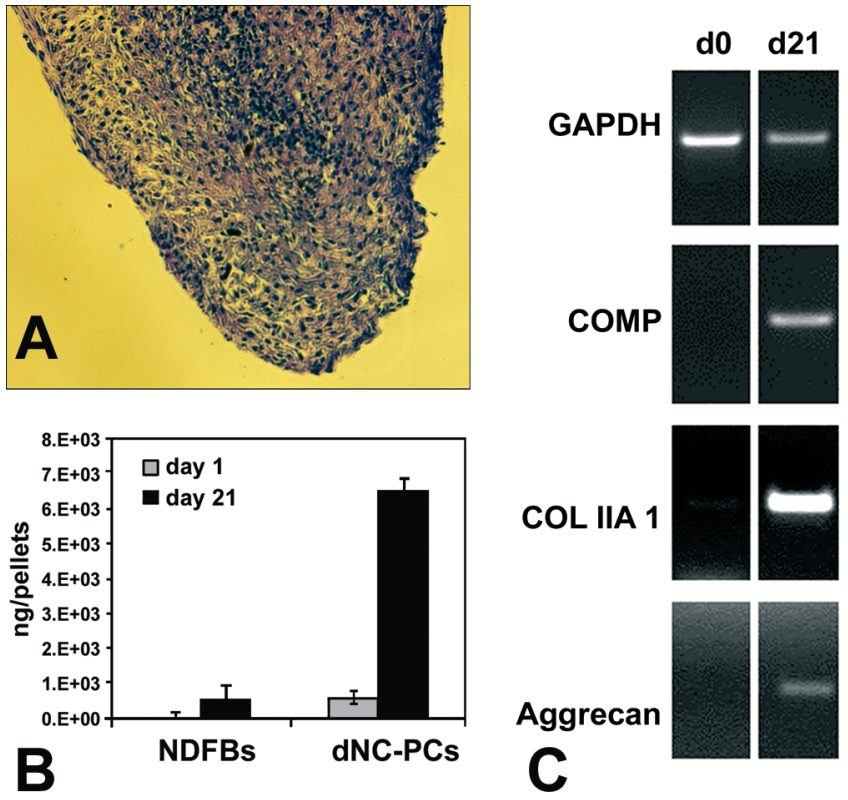

FIG. 5. Characterization of dNC-PCs after chondrogenic stimulation. Histology of pellet cultures after 21 days of stimulation stained by toluidine blue $(\mathbf{A}, \times 100)$. Quantification of S-GAGs in pellet cultures of dNC-PCs (B). The totality of S-GAGs was upregulated after 21 days of culture when compared to controls, that is, nonstimulated cells and NDFBs. RT-PCR of pellet cultures after 21 days of stimulation (C). Note upregulation of cartilage oligomeric protein (COMP), collagen type II $\alpha 1$ chain (COL IIA 1 ), and aggrecan. GAPDH served as a housekeeping gene. Color images available online at www.liebertpub.com/ten.

In the developing head region, first signs of tooth development become visible when the primary epithelial band and the underlying concentrations of cranial neural crestderived mesenchyme are formed along the crest of the upper and lower jaws. ${ }^{28}$ During dental development, selective cell-cell and cell-matrix interactions take their places and are found to form the complex tissue of the tooth. ${ }^{29}$ As shown here, the pad-like tissue represents a specific compartment in the developing tooth. The pad-like tissue found to be different from pulp/papilla and the follicle/periodontal ligament, not only by gross morphology but also by histology. Histological analysis showed a loose mesenchymal connective tissue with undifferentiated cells sparsely distributed within their matrix. With respect to the phenotype of cells, neither odontoblast-like cells nor dental follicle cells were observed in this location. Although we need more detailed information, our data may point to matrix condition within the pad-like tissue that is different from other compartments. Indeed, the matrix should play an active and complex role in regulating the behavior of the cells by influencing the development, shape, migration, proliferation, and metabolic functions of the neighboring cells that are in contact with it. Therefore, we treated the pad-like tissue as a unique structure.
Using the pad-like tissue, we isolated dNC-PCs. Interestingly, there are several reports of pluripotent neural crest cells that could be isolated from their niche not only from developing tissues but also from differentiated tissues up to adulthood. For example, the ectomesenchymal cells in the first branchial arch from the mandibular processes of mice were isolated and maintained in an intact state in growth medium. ${ }^{30,31}$ In the mammalian skin, dNC-PCs were described to be isolated from the dermal papillae ${ }^{32}$ and the epidermal bulge area of hair follicles ${ }^{33,34}$ that behave in vitro and in vivo as pluripotent stem cells. Accordingly, the padlike tissue of impacted teeth represents an ideal source for recovery of dNC-PCs in human.

Previous attempts to isolate stem cells from dental tissues have focused on suspension cultures after enzyme treatment from adult patients (up to $18-45$ years). ${ }^{14,16,17,35,36}$ In contrast, we used tissues of young donors as a source for progenitor cells. Due to the emigration ability of the dNC$\mathrm{PCs}$, the cell population is morphologically homogenous and expresses a unique set of surface markers distinguishing these cells not only from stem/progenitor cells derived from the bone marrow, ${ }^{37}$ but also from dental pulp $^{14}$ and periodontal ligament. ${ }^{17}$ In fact, dNC-PCs do not express STRO-1 and are clearly nonendothelial $\left(\mathrm{CD} 31^{-}\right)$, nonepithelial (pan-cytokeratin ${ }^{-}$), and nonhematopoietic cells (CD14 ${ }^{-}, \mathrm{CD}^{-} 5^{-}, \mathrm{CD}_{4} 4^{-}$, and class II HLA $\left.{ }^{-}\right)$. dNC-PCs express a large number of adhesion molecules, integrins, and growth factor receptors that may be used as criteria for classification of these cells.

Among all these molecules, PDGFR $\alpha$, CD56 (NCAM), and $\mathrm{CD} 49 \mathrm{~d}(\alpha 4$ integrin) are the most important markers because they play a major role in migratory properties of cells of neural crest origin. Fitting well with this observation, dNC-PCs are identified as migratory cells that arise from microexplants in the beginning of cell culture. Moreover, as we found PDGFR $\alpha$, NCAM, and $\alpha 4$ integrin to be expressed in cells when growing as a monolayer, we suggest that the expression of these molecules may be typical for dNC-PCs when becoming motile. Thus, it may be worthwhile to explore the distinct expression patterns of these markers during differentiation of dNC-PCs. Literature data demonstrated that PDGFR $\alpha$ is expressed during craniofacial development in a subset of nonneuronal neural crest cells where PDGFR $\alpha$ probably regulates migration of cells to their destinations. ${ }^{38,39}$ PDGFR $\alpha$ has also been indicated in differentiation of embryonic neural stem cells into glial cells, such as astrocytes or oligodendrocytes. ${ }^{40}$ Accordingly, in the spinal cord and cortex, the expression of PDGFR $\alpha$ served as a marker for oligodendrocyte and neuron precursors. ${ }^{41,42} \mathrm{NCAM}$, in concert with other cell and substrate adhesion molecules, is associated in processes of emigration and early migration of neural crest cells. The prolonged retention of NCAM on crest cells after their exit from the neuroepithelium to their pharyngeal arch destinations has been demonstrated. ${ }^{43}$ Interestingly, NCAM is also found in human adult craniofacial muscle-derived cells, 

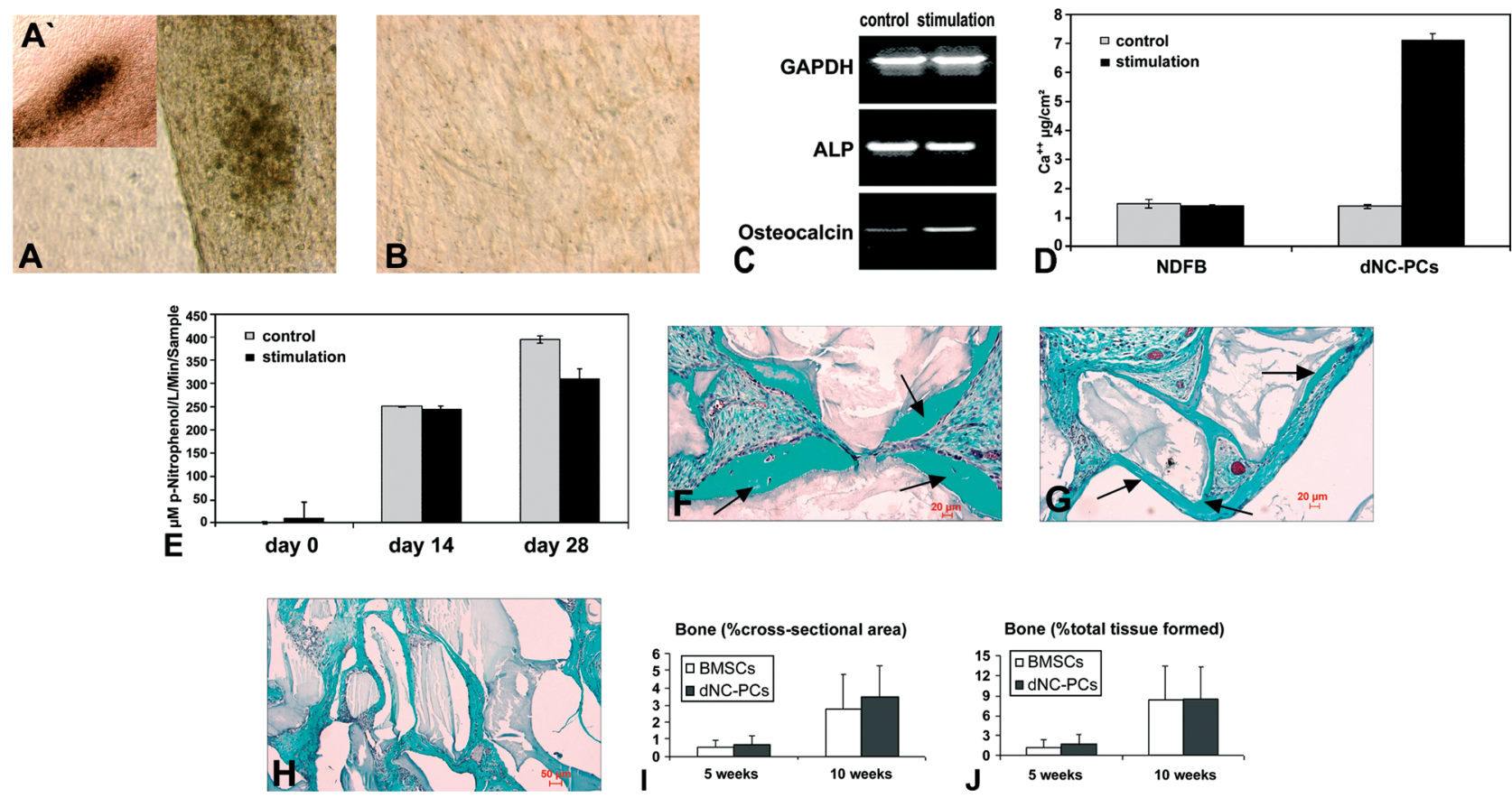

FIG. 6. Characterization of dNC-PCs after osteogenic stimulation. View of stimulated $\left(\mathbf{A}, \times 100\right.$; inset $\left.\mathrm{A}^{\prime}, \times 50\right)$ and nonstimulated $(\mathbf{B}$, $\times 100$ ) cultures when grown for 21 days stained by von Kossa. Note mineralization (dark deposits) in treated cultures. RT-PCR of dNCPCs after 28 days of stimulation (C). Note upregulation of osteocalcin while alkaline phosphatase (ALP) remained unchanged. GAPDH served as a housekeeping gene. Quantification of calcium (D) and of alkaline phosphatase activity (E) in dNC-PCs after osteogenic stimulation. The content of calcium was clearly upregulated after 21 days of culture when compared to controls, that is, nonstimulated cells and NDFBs. Alkaline phosphatase activity was detectable equally in both stimulated cells and controls over all days. In vivo osteogenesis of dNC-PCs after ectopic implantation in nude mice $(\mathbf{F}-\mathbf{J})$. Histology $(\mathbf{F}-\mathbf{H})$ and quantification $(\mathbf{I}, \mathbf{J})$ of bone tissue formation. Representative cross sections of constructs generated by dNC-PCs (F) or bone marrow stromal cells (G) using Bio-Oss scaffolds stained by Masson trichrome. Scaffolds not loaded with cells are shown in (H). Bone formation is indicated by arrows. Samples were assessed at 10 weeks. Quantification of bone formation was done by computerized histomorphometry and assessed at 5 and 10 weeks (I, J). Bone tissue amount is expressed as a percentage of the total implant area (I) or of the total space available for tissue ingrowth $(\mathbf{J})$. Statistically significant differences $(p<0.05)$ between dNC-PCs and bone marrow-derived stromal cells $(B M S C s)$ were not observed. Color images available online at www.liebertpub.com/ten.

where NCAM-positive subpopulations were shown to be able to form nonmuscle tissue, such as fat and bone. ${ }^{44}$ Integrins that contain the $\alpha 4$ subunit are involved in cranial neural crest emigration from the neural tube and subsequent migration, and represent a useful marker for neural crest cells at both cranial and trunk levels. ${ }^{45,46}$ Here, further experiments are necessary to show the integrin $\beta$ subunit with which the integrin $\alpha 4$ subunit of dNC-PCs heterodimerizes to form a receptor enabling the interaction with the extracellular matrix. In addition to the above-mentioned molecules, the dNC-PCs were also identified by the expression of transcription factor genes like Snaill, Snail2, Twist1, Sox9, $D l x 6$, and $M s x 2$. Each of these genes is known to be involved in development of neural crest and neural crest cell differentiation, respectively. ${ }^{47-54}$ Altogether, our findings suggest that the pad-like tissue contains progenitor cells, that is, dNC-PCs, the origin of which is the neural crest.

Up to now several populations of stem or progenitor cells were found in the dental tissue. For example, the identifi- cation and isolation of cells from the pulp tissue obtained from adults, ${ }^{14}$ human exfoliated deciduous teeth, ${ }^{15}$ periodontal ligament, ${ }^{17}$ and root papilla ${ }^{16}$ have been reported. However, not only molecular characteristics but also functional features of dNC-PCs make it reasonable to assume that these cells differ from dental stem cell populations described so far. Gronthos et al. ${ }^{14}$ reported that dental pulpderived stem cells gave rise to adherent cells, which expressed STRO-1 surface antigens. Interestingly, these cells have the ability to differentiate in dentin/pulp-like complex. Moreover, Miura et al. ${ }^{15}$ isolated STRO-1-positive stem cells from human exfoliated deciduous teeth that differentiated into odontoblast, adipocytes, and neural-like cells, respectively, but not into chondrocytes or osteocytes. Morsczeck et al..$^{55}$ described cells from dental follicle/ periodontal ligament, which, however, did not form bone tissue or cementum in vivo. More recently, a subpopulation of dental stem cells positive for STRO-1, CD34 ${ }^{+}$, and $\mathrm{CD} 117^{+}$has been isolated, which spontaneously differen- 
tiated into osteoblasts without any osteogenic stimulation and showed differentiation potential for myogenic and adipogenic lineages. ${ }^{36,56}$ With regard to root apical papilla, ${ }^{16}$ again, STRO- $1^{+}$-positive cells expressing high values of CD106 and low values of CD105 were cultured. These cells were shown to differentiate into odontoblast-like cells and adipocytes in vitro and displayed dentin/pulp regenerative capacity in vivo. ${ }^{16}$ In contrast, in our study we were able to establish primary cells in vitro that showed positive labeling for CD49d ( $\alpha 4$ integrin), CD56 (NCAM), and PDGFR $\alpha$ and no labeling for STRO-1 because we used pad-like tissue to generate dNC-PCs instead of the complete dental papilla. Therefore, we assume that mostly undifferentiated ectomesenchymal cells contribute to the formation of progenitor cells in our culture system. Indeed, we verified that dNC-PCs showed many characteristics of multipotency in vitro and even in vivo. When STRO-1-negative dNC$\mathrm{PCs}$, which differentiated into osteoblasts only with osteogenic stimulation (see "osteogenic differentiation" under "Results"), were dissociated into a suspension of single cells, subsequently loaded on ceramic scaffolds, and then implanted in athymic mice, bone rather than dentin was formed. Although it is not yet understood how dNC-PCs in the nude mouse system adapt their destiny to the new environmental conditions, our data demonstrate the broad responsiveness of dNC-PCs to signals other than of dental origin and demonstrate differences to previously described dental stem cells.

\section{CONCLUSION}

Pad-like tissue-derived cells are neural crest-derived ectomesenchymal progenitor cells with a high capacity for diversification when taken out of their signaling network, that is, being independent from those indicative and permissive interactions resulting in formation of periodontal tissues. This includes neurogenic, chondrogenic, and osteogenic lineages. Hence, pad-like tissue-derived cells may provide a model system for a generation of diverse cell types from pluripotent neural crest. ${ }^{57}$ As a rather large amount of cells was obtained from each pad-like tissue that we cultured, they may be easily used as tools to regenerate neural crest-derived tissues within the craniofacial region.

\section{ACKNOWLEDGMENTS}

The skillful technical assistance of Cornelia Sippel, Sandra Pohl, Inka Bay, and Nicholas Wagner is acknowledged with great gratitude. We thank Allesandra Braccini, Oliver Schuefler, and Andrea Galli for support with the quantitative analysis of in vivo osteogenesis. Special thanks to Jolanta Krämer for language editing of the manuscript and Corinna Bernsdorff for help with processing of images.
We thank H.F. Zeilhofer for providing us with the animal facility and for his interest in this work. Sincere thanks to K.H. Hoffmann for his encouragement at the beginning of this work.

\section{REFERENCES}

1. Chai, Y., and Maxson, R.E., Jr. Recent advances in craniofacial morphogenesis. Dev Dyn 235(9), 2353-2375, 2006.

2. Le Douarin, N.M., Dupin, E., and Ziller, C. Genetic and epigenetic control in neural crest development. Curr Opin Genet Dev 4(5), 685-695, 1994.

3. Dupin, E., Creuzet, S., and Le Douarin, N.M. The contribution of the neural crest to the vertebrate body. Adv Exp Med Biol 589, 96-119, 2006.

4. Osumi-Yamashita, N., Noji, S., Nohno, T., Koyama, E., Doi, H., Eto, K., and Taniguchi, S. Expression of retinoic acid receptor genes in neural crest-derived cells during mouse facial development. FEBS Lett 264(1), 71-74, 1990.

5. Serbedzija, G.N., Bronner-Fraser, M., and Fraser, S.E. Vital dye analysis of cranial neural crest cell migration in the mouse embryo. Development 116(2), 297-307, 1992.

6. Selleck, M.A., Scherson, T.Y., and Bronner-Fraser, M. Origins of neural crest cell diversity. Dev Biol 159(1), 1-11, 1993.

7. Bronner-Fraser, M. Neural crest cell migration in the developing embryo. Trends Cell Biol 3(11), 392-397, 1993.

8. Lumsden, A., and Krumlauf, R. Patterning the vertebrate neuraxis. Science 274(5290), 1109-1115, 1996.

9. Yamashiro, T., Aberg, T., Levanon, D., Groner, Y., and Thesleff, I. Expression of Runx1, -2 and -3 during tooth, palate and craniofacial bone development. Mech Dev 119 Suppl 1, S107-S110, 2002.

10. Imai, H., Osumi-Yamashita, N., Ninomiya, Y., and Eto, K. Contribution of early-emigrating midbrain crest cells to the dental mesenchyme of mandibular molar teeth in rat embryos. Dev Biol 176(2), 151-165, 1996.

11. Chai, Y., Jiang, X., Ito, Y., Bringas, P., Jr., Han, J., Rowitch, D.H., Soriano, P., McMahon, A.P., and Sucov, H.M. Fate of the mammalian cranial neural crest during tooth and mandibular morphogenesis. Development 127(8), 1671-1679, 2000.

12. Schroeder, H.E. The Periodontium. Handbook of Microscopic Anatomy. Berlin: Springer; 1986.

13. Helms, J.A., Cordero, D., and Tapadia, M.D. New insights into craniofacial morphogenesis. Development 132(5), 851861, 2005.

14. Gronthos, S., Mankani, M., Brahim, J., Robey, P.G., and Shi, S. Postnatal human dental pulp stem cells (DPSCs) in vitro and in vivo. Proc Natl Acad Sci USA 97(25), 13625-13630, 2000 .

15. Miura, M., Gronthos, S., Zhao, M., Lu, B., Fisher, L.W., Robey, P.G., and Shi, S. SHED: stem cells from human exfoliated deciduous teeth. Proc Natl Acad Sci USA 100(10), 5807-5812, 2003.

16. Sonoyama, W., Liu, Y., Fang, D., Yamaza, T., Seo, B.M., Zhang, C., Liu, H., Gronthos, S., Wang, C.Y., Shi, S., and Wang, S. Mesenchymal stem cell-mediated functional tooth regeneration in Swine. PLoS ONE 1, e79, 2006.

17. Seo, B.M., Miura, M., Gronthos, S., Bartold, P.M., Batouli, S., Brahim, J., Young, M., Robey, P.G., Wang, C.Y., and Shi, S. 
Investigation of multipotent postnatal stem cells from human periodontal ligament. Lancet 364(9429), 149-155, 2004.

18. Bepler, G., Jaques, G., Neumann, K., Aumuller, G., Gropp, C., and Havemann, K. Establishment, growth properties, and morphological characteristics of permanent human small cell lung cancer cell lines. J Cancer Res Clin Oncol 113(1), 31-40, 1987.

19. Serakinci, N., Guldberg, P., Burns, J.S., Abdallah, B., Schrodder, H., Jensen, T., and Kassem, M. Adult human mesenchymal stem cell as a target for neoplastic transformation. Oncogene 23(29), 5095-5098, 2004.

20. Rubio, D., Garcia-Castro, J., Martin, M.C., de la Fuente, R., Cigudosa, J.C., Lloyd, A.C., and Bernad, A. Spontaneous human adult stem cell transformation. Cancer Res $\mathbf{6 5}(8)$, 3035-3039, 2005.

21. Miura, M., Miura, Y., Padilla-Nash, H.M., Molinolo, A.A., Fu, B., Patel, V., Seo, B.M., Sonoyama, W., Zheng, J.J., Baker, C.C., Chen, W., Ried, T., and Shi, S. Accumulated chromosomal instability in murine bone marrow mesenchymal stem cells leads to malignant transformation. Stem Cells 24(4), 1095-1103, 2006.

22. Kogler, G., Sensken, S., Airey, J.A., Trapp, T., Muschen, M., Feldhahn, N., Liedtke, S., Sorg, R.V., Fischer, J., Rosenbaum, C., Greschat, S., Knipper, A., Bender, J., Degistirici, O., Gao, J., Caplan, A.I., Colletti, E.J., Almeida-Porada, G., Muller, H.W., Zanjani, E., and Wernet, P. A new human somatic stem cell from placental cord blood with intrinsic pluripotent differentiation potential. J Exp Med 200(2), 123-135, 2004.

23. Johnstone, B., Hering, T.M., Caplan, A.I., Goldberg, V.M., and Yoo, J.U. In vitro chondrogenesis of bone marrowderived mesenchymal progenitor cells. Exp Cell Res 238(1), 265-272, 1998.

24. Bruder, S.P., Jaiswal, N., and Haynesworth, S.E. Growth kinetics, self-renewal, and the osteogenic potential of purified human mesenchymal stem cells during extensive subcultivation and following cryopreservation. J Cell Biochem 64(2), 278-294, 1997.

25. Jaquiery, C., Schaeren, S., Farhadi, J., Mainil-Varlet, P., Kunz, C., Zeilhofer, H.F., Heberer, M., and Martin, I. In vitro osteogenic differentiation and in vivo bone-forming capacity of human isogenic jaw periosteal cells and bone marrow stromal cells. Ann Surg 242(6), 859-867, 2005 (discussion).

26. Braccini, A., Wendt, D., Jaquiery, C., Jakob, M., Heberer, M., Kenins, L., Wodnar-Filipowicz, A., Quarto, R., and Martin, I. Three-dimensional perfusion culture of human bone marrow cells and generation of osteoinductive grafts. Stem Cells 23(8), 1066-1072, 2005.

27. Enobakhare, B.O., Bader, D.L., and Lee, D.A. Quantification of sulfated glycosaminoglycans in chondrocyte/alginate cultures, by use of 1,9-dimethylmethylene blue. Anal Biochem 243(1), 189-191, 1996.

28. Ten Cate, A.R. Development of the Tooth and Its Supporting Tissues. Oral Histology. Sixth edition. St. Louis, London: Mosby, 2003, pp. 79-110.

29. Thesleff, I., and Sharpe, P. Signalling networks regulating dental development. Mech Dev 67(2), 111-123, 1997.

30. Deng, M.J., Jin, Y., Shi, J.N., Lu, H.B., Liu, Y., He, D.W., Nie, X., and Smith, A.J. Multilineage differentiation of ectomesenchymal cells isolated from the first branchial arch. Tissue Eng 10(9-10), 1597-1606, 2004.
31. Lin, Y., Yan, Z., Liu, L., Qiao, J., Jing, W., Wu, L., Chen, X., Li, Z., Tang, W., Zheng, X., and Tian, W. Proliferation and pluripotency potential of ectomesenchymal cells derived from first branchial arch. Cell Prolif 39(2), 79-92, 2006.

32. Toma, J.G., Akhavan, M., Fernandes, K.J., Barnabe-Heider, F., Sadikot, A., Kaplan, D.R., and Miller, F.D. Isolation of multipotent adult stem cells from the dermis of mammalian skin. Nat Cell Biol 3(9), 778-784, 2001.

33. Sieber-Blum, M., Grim, M., Hu, Y.F., and Szeder, V. Pluripotent neural crest stem cells in the adult hair follicle. Dev Dyn 231(2), 258-269, 2004.

34. Sieber-Blum, M., Schnell, L., Grim, M., Hu, Y.F., Schneider, R., and Schwab, M.E. Characterization of epidermal neural crest stem cell (EPI-NCSC) grafts in the lesioned spinal cord. Mol Cell Neurosci 32(1-2), 67-81, 2006.

35. Shi, S., Robey, P.G., and Gronthos, S. Comparison of human dental pulp and bone marrow stromal stem cells by cDNA microarray analysis. Bone 29(6), 532-539, 2001.

36. Laino, G., d'Aquino, R., Graziano, A., Lanza, V., Carinci, F., Naro, F., Pirozzi, G., and Papaccio, G. A new population of human adult dental pulp stem cells: a useful source of living autologous fibrous bone tissue (LAB). J Bone Miner Res 20(8), 1394-1402, 2005.

37. Pittenger, M.F., Mackay, A.M., Beck, S.C., Jaiswal, R.K., Douglas, R., Mosca, J.D., Moorman, M.A., Simonetti, D.W., Craig, S., and Marshak, D.R. Multilineage potential of adult human mesenchymal stem cells. Science 284(5411), 143147, 1999.

38. Morrison-Graham, K., Schatteman, G.C., Bork, T., BowenPope, D.F., and Weston, J.A. A PDGF receptor mutation in the mouse (Patch) perturbs the development of a non-neuronal subset of neural crest-derived cells. Development 115(1), 133142, 1992.

39. Soriano, P. The PDGF alpha receptor is required for neural crest cell development and for normal patterning of the somites. Development 124(14), 2691-2700, 1997.

40. Dai, C., Celestino, J.C., Okada, Y., Louis, D.N., Fuller, G.N., and Holland, E.C. PDGF autocrine stimulation dedifferentiates cultured astrocytes and induces oligodendrogliomas and oligoastrocytomas from neural progenitors and astrocytes in vivo. Genes Dev 15(15), 1913-1925, 2001.

41. Hall, A., Giese, N.A., and Richardson, W.D. Spinal cord oligodendrocytes develop from ventrally derived progenitor cells that express PDGF alpha-receptors. Development 122(12), 4085-4094, 1996.

42. Cai, J., Wu, Y., Mirua, T., Pierce, J.L., Lucero, M.T., Albertine, K.H., Spangrude, G.J., and Rao, M.S. Properties of a fetal multipotent neural stem cell (NEP cell). Dev Biol 251(2), 221-240, 2002.

43. Peterson, P.E., Blankenship, T.N., Wilson, D.B., and Hendrickx, A.G. Analysis of hindbrain neural crest migration in the long-tailed monkey (Macaca fascicularis). Anat Embryol (Berl) 194(3), 235-246, 1996.

44. Sinanan, A.C., Hunt, N.P., and Lewis, M.P. Human adult craniofacial muscle-derived cells: neural-cell adhesion-molecule (NCAM; CD56)-expressing cells appear to contain multipotential stem cells. Biotechnol Appl Biochem 40 (Pt 1), 25-34, 2004.

45. Pinco, K.A., Liu, S., and Yang, J.T. Alpha4 integrin is expressed in a subset of cranial neural crest cells and in 
epicardial progenitor cells during early mouse development. Mech Dev 100(1), 99-103, 2001.

46. Kil, S.H., Krull, C.E., Cann, G., Clegg, D., and BronnerFraser, M. The alpha4 subunit of integrin is important for neural crest cell migration. Dev Biol 202(1), 29-42, 1998.

47. Deflorian, G., Tiso, N., Ferretti, E., Meyer, D., Blasi, F., Bortolussi, M., and Argenton, F. Prep1.1 has essential genetic functions in hindbrain development and cranial neural crest cell differentiation. Development 131(3), 613-627, 2004.

48. Sasaki, T., Ito, Y., Bringas, P., Jr., Chou, S., Urata, M.M., Slavkin, H., and Chai, Y. TGFbeta-mediated FGF signaling is crucial for regulating cranial neural crest cell proliferation during frontal bone development. Development 133(2), 371381, 2006.

49. Ishii, M., Merrill, A.E., Chan, Y.S., Gitelman, I., Rice, D.P., Sucov, H.M., and Maxson, R.E., Jr. Msx2 and Twist cooperatively control the development of the neural crest-derived skeletogenic mesenchyme of the murine skull vault. Development 130(24), 6131-6142, 2003

50. Hong, C.S., and Saint-Jeannet, J.P. Sox proteins and neural crest development. Semin Cell Dev Biol 16(6), 694-703, 2005.

51. Pomp, O., Brokhman, I., Ben-Dor, I., Reubinoff, B., and Goldstein, R.S. Generation of peripheral sensory and sympathetic neurons and neural crest cells from human embryonic stem cells. Stem Cells 23(7), 923-930, 2005.

52. Takahashi, K., Nuckolls, G.H., Takahashi, I., Nonaka, K., Nagata, M., Ikura, T., Slavkin, H.C., and Shum, L. Msx2 is a repressor of chondrogenic differentiation in migratory cranial neural crest cells. Dev Dyn 222(2), 252-262, 2001.

53. Charite, J., McFadden, D.G., Merlo, G., Levi, G., Clouthier, D.E., Yanagisawa, M., Richardson, J.A., and Olson, E.N Role of Dlx6 in regulation of an endothelin-1-dependent, dHAND branchial arch enhancer. Genes Dev 15(22), 30393049, 2001.
54. Fernandes, K.J., McKenzie, I.A., Mill, P., Smith, K.M., Akhavan, M., Barnabe-Heider, F., Biernaskie, J., Junek, A., Kobayashi, N.R., Toma, J.G., Kaplan, D.R., Labosky, P.A., Rafuse, V., Hui, C.C., and Miller, F.D. A dermal niche for multipotent adult skin-derived precursor cells. Nat Cell Biol 6(11), 1082-1093, 2004.

55. Morsczeck, C., Gotz, W., Schierholz, J., Zeilhofer, F., Kuhn, U., Mohl, C., Sippel, C., and Hoffmann, K.H. Isolation of precursor cells (PCs) from human dental follicle of wisdom teeth. Matrix Biol 24(2), 155-165, 2005.

56. Laino, G., Graziano, A., d'Aquino, R., Pirozzi, G., Lanza, V., Valiante, S., De, R.A., Naro, F., Vivarelli, E., and Papaccio, G. An approachable human adult stem cell source for hardtissue engineering. J Cell Physiol 206(3), 693-701, 2006.

57. Le Douarin, N.M., Creuzet, S., Couly, G., and Dupin, E. Neural crest cell plasticity and its limits. Development 131(19), 4637-4650, 2004.

Address reprint requests to: Özer Degistirici, Ph.D.

Center of Advanced European Studies and Research (CAESAR)

Ludwig-Erhard-Allee 2 D-53175 Bonn Germany

E-mail: degistirici@caesar.de

Michael Thie, Ph.D.

Center of Advanced European Studies and Research

(CAESAR)

Ludwig-Erhard-Allee 2

D-53175 Bonn

Germany

E-mail:thie@caesar.de 


\section{This article has been cited by:}

1. A. Bakopoulou, G. Leyhausen, J. Volk, P. Koidis, W. Geurtsen. 2013. Comparative characterization of STRO-1neg/CD146pos and STRO-1pos/CD146pos apical papilla stem cells enriched with flow cytometry. Archives of Oral Biology . [CrossRef]

2. Christian Morsczeck, George T.-J. Huang, Songtao ShiStem and Progenitor Cells of Dental and Gingival Tissue Origin 285-302. [CrossRef]

3. Martin Gosau, Werner Götz, Oliver Felthaus, Tobias Ettl, Andreas Jäger, Christian Morsczeck. 2012. Comparison of the differentiation potential of neural crest derived progenitor cells from apical papilla (dNC-PCs) and stem cells from exfoliated deciduous teeth (SHED) into mineralising cells. Archives of Oral Biology . [CrossRef]

4. Özer Degistirici, Florian Grabellus, Stephan Irsen, Kurt Werner Schmid, Michael Thie. 2010. Using human neural crest-derived progenitor cells to investigate osteogenesis: An in vitro study. Matrix Biology 29:3, 219-227. [CrossRef]

5. Frank Bäumchen, Daniel Koch, Hans Georg Gräber. 2009. Untersuchungen zum Design dreidimensionaler textiler Trägermaterialien für das Tissue Engineering in vitro : eine Pilotstudie / Structure design examinations of three-dimensional textile scaffolds employed for tissue engineering in vitro : a pilot study. Biomedizinische Technik/Biomedical Engineering 54:6, 357-366. [CrossRef]

6. R. Kaneko, H. Akita, H. Shimauchi, Y. Sasano. 2009. Immunohistochemical localization of the STRO-1 antigen in developing rat teeth by light microscopy and electron microscopy. Journal of Electron Microscopy 58:6, 363-373. [CrossRef]

7. Erik J. Woods, Brandon C. Perry, J. Jeffrey Hockema, Lindsay Larson, Dan Zhou, W. Scott Goebel. 2009. Optimized cryopreservation method for human dental pulp-derived stem cells and their tissues of origin for banking and clinical use\#. Cryobiology 59:2, 150-157. [CrossRef]

8. Caroline Brandl, Christian Florian, Oliver Driemel, Bernhard H.F. Weber, Christian Morsczeck. 2009. Identification of neural crest-derived stem cell-like cells from the corneal limbus of juvenile mice. Experimental Eye Research 89:2, 209-217. [CrossRef]

9. Fabienne C. Fierz, Felix Beckmann, Marius Huser, Stephan H. Irsen, Barbara Leukers, Frank Witte, Özer Degistirici, Adrian Andronache, Michael Thie, Bert Müller. 2008. The morphology of anisotropic 3D-printed hydroxyapatite scaffolds. Biomaterials 29:28, 3799-3806. [CrossRef] 